\title{
PENGARUH PENDAPATAN MURABAHAH DAN PENDAPATAN IJARAH TERHADAP LABA BERSIH
}

Gita Oktaviani Sindhu

Universitas Singaperbangsa Karawang gitasindhu07@gmail.com

\section{Isro'iyatul Mubarokah}

Universitas Singaperbangsa Karawang

isroiyatul.mubarokah@fe.unsika.ac

\begin{abstract}
This research was conducted to determine the effect of murabahah income and ijarah income on the net profit of Islamic commercial banks for the period 2013-2019, either partially or simultaneously. In this research, the method used is descriptive method and verification method with a quantitative approach. The sample used in this study amounted to 3 Islamic commercial banks. The results of this study indicate that (1) Partial murabahah income has a positive and significant effect on net income. (2) Partial ijarah income has no and insignificant effect on net income. (3) Murabahah income and ijarah income simultaneously have a positive and significant effect on net income.
\end{abstract}

Keywords: Murabahah income, Ijarah income, net profit

\section{PENDAHULUAN}

Indonesia termasuk kedalam penduduk muslim terbanyak didunia. Perekonomian Indonesia didukung oleh perbankan, hampir seluruh kegiatan ekonomi memerlukan bank untuk mendukung pelaku usaha dalam mengembangkan usahanya. Perbankan konvensional telah menerapkan sistem bunga pada produk perbankannya namun berbeda pada perbankkan syariah yang telah menerapkan teknik bagi hasil pada produk perbankannya. Berdasarkan UU No 10 Tahun 1998, bank umum syariah ialah bank umum yang menerapkan aktivitas usahanya dengan didasarkan kaidah ajaran islam dan memberikan jasa pembaayaran dalam kegiatannya. Dengan adanya penerapan sistem ekonomi berdasarkan prinsip syariah diharapkan dapat meningkatkan kesejahteraan ekonomi bagi masyarakat.

Produk yang dihasilkan perbankan syariah salah satunya adalah produk penyaluran dana. Dalam menyalurkan dana untuk nasabah terdapat berbagai macam pembiayaan, salah satunya yaitu pembiayaan murabahah yang merupakan kegiatan yang dilakukan pihak bank untuk membeli barang yang diperlukan pelanggan dan ditambahkan dengan keuntungan yang sudah disepakati. Selanjutnya, ada pembiayaan ijarah yang merupakan perjanjian yang di lakukan oleh nasabah kepada bank syariah atas pemindahan hak suatu barang berdasarkan jangka waktu yang telah disepakati melalui 
dengan pembayaran sewa namun tidak atas kepemilikannya. Penghasilan ialah peningkatan manfaat ekonomi berupa penambahan aset atau hutang menurun yang mengarah pada kenaikan modal namun tidak bersumber dari investor.

Menurut Hendrieta Ferieka (2016:32) Laba merupakan hasil pengurangan yang diperoleh dari pendapatan dengan biayabiaya pada periode akuntansi, dan dapat mengalami kerugian jika dalam kondisi sebaliknya. Laba bersih ialah salah satu petunjuk penting dalam menentukan keberhasilan kinerja perbankan. Pendapatan murabahah dan pendapatan ijarah adalah salah satu sumber pendapatan perbankan syariah yang berpengaruh pada laba bersih. Faktor-faktor yang dapat mempengaruhi tingkat pendapatan bank yaitu faktor didalam perusahaan seperti dari keuntungan atas transaksi jual beli , keuntungan bagi hasil, dan pendapatan biaya dan ada faktor eksternal yang tidak dapat dihindari. Meningkatnya pendapatan murabahah dan pendapatan ijarah yang dihasilkan maka dapat meningkatkan laba bersih. Sedangkan jika pendapatan murabahah dan pendapatan ijarah menurun maka dapat berdampak pada penurunan laba bersih. Ada beberapa bank umum syari'ah yang mengalami pergerakkan fluktuatif. Hal tersebut dikarenakan nasabah yang tidak atau telat dalam membayar angsuran kewajibannya atas pembiayaan murabahah dan ijarah kepada pihak bank. Berdasarkan penjelasan tersebut , maka penelitibertujuan untuk menganalisis pengaruh Pendapatan Murabahah Dan Pendapatan Ijarah Terhadap Laba Bersih Pada Bank Umum Syariah.

\section{TINJAUAN PUSTAKA DAN PENGEMBANGAN HIPOTESIS}

\section{Perbankan Syariah}

Bank syariah ialah prosedur yang menjalankan aktivitasnya sesuai dengan syariat islam. Menurut Sudarsono (2012:29) menjelaskan bahwa bank syariah ialah lembaga yang bertujuan untuk memberikan pinjaman kepada nasabah serta layanan lainnya dalam bisnis pembayaran yang beroperasi menurut hukum syariah. Bank syariah berguna untuk penyaluran dana pada nasabah berupa bagi hasil, menghimpun dana dan memberikan layanan jasa bank seperti memberikan jasa tarik tunai, jasa transfer dan lainnya.

\section{Murabahah}

Suatu bentuk penyaluran dana dalam bank syariah adalah dengan adanya produk pembiayaan murabahah. Menurut Djamil (2013:108) murabahah adalah perjanjian dalam menyediakan barang, dimana pihak bank membelikan barang sesuai keinginan pelanggan lalu dijual kembali pada nasabah serta ditambah dengan keuntungan yang di sepakati. Dapat disimpulkan bahwa Murabahah ialah perjanjian jual-beli yang keuntungan pihak bank sudah disepakati oleh pihak bank dan nasabah saat awal perjanjian, begitu pula dengan harga jualnya. Sehingga pihak bank akan menjelaskan harga suatu barang kepada nasabah dan kemudian akan membagi sejumlah harga tertentu sesuai kesepakatan.

Keutamaan dari produk pembiayaan murabahah ialah pembayaran untuk produk pembiayaan murabahah dapat dilakukan secara berangsur sehingga tidak 
memberatkan nasabah. Adapun keutamaan lainnya yaitu tidak adanya riba pada kegiatan jual beli tersebut.

Menurut Muljono (2015:147) pembiayaan murabahah terdiri dari murabahah pesanan yaitu murabahah yang bersifat saling terikat yang artinya nasabah tidak dapat membatalkan pesanan kepada pihak bank. Namun jika nilai barang yang dipesan nasabah menurun sebelum dikirim ke pelanggan, hal ini menjadi tanggung jawab penjual. Sedangkan barang tanpa pesanan bersifat tidak saling terikat yang berarti nasabah atau pembeli dapat membatalkan pesanannya karena penjual atau pihak bank menjual barang tanpa adanya pesanan terlebih dahulu. Selanjutnya murabahah tunai merupakan perjanjian jual beli yang pembayarannya dilakukan sekaligus pada saat penyerahan barang dan murabahah tangguh merupakan murabahah yang pembayarannya dilakukan secara berangsur sesuai kesepakatan kedua belah pihak.

\section{Ijarah}

Menurut Nurhayati (2013:228) Alijarah dapat diartikan dengan perjanjian yang telah disetujui untuk mengalihkan hak untuk menggunakan suatu barang melalui pembayaran sewa dalam jangka waktu yang telah disepakati, tanpa mengalihkan kepemilikan barang tersebut.

Menurut Fatwa DSN 09/DSNMUI/IV/2000 mengenai ijarah ialah pihak yang bersangkutan seperti pemberi sewa yaitu bank syariah dan penyewa yaitu nasabah, selanjutnya objek dari perjanjian ijarah adalah manfaat barang ataupun upah sewa, dan sighat ijarah yang berarti pernyataan kedua belah pihak.

\section{Laba bersih}

Menurut kasmir (2011:303) laba bersih ialah keuntungan yang dihasilkan sesudah dikurang biaya operasional perusahaan pada periode tertentu dan pajak. Berdasarkan definisi tersebut laba bersih dihasilkan atau dihitung dengan mengurangkan beban perusahaan dan pajak penghasilan perusahaan.

Semakin besar perusahaan memperoleh laba bersih maka semakin baik perusahaan dalam membayarkan biaya selain operasi dan pajak penghasilan serta dapat mengetahui kemampuan perusahaan dalam mendapatkan laba. Menurut Mulyanti (2019) tingginya pendapatan bank dapat dipengaruhi oleh tingkat pembiayaan yang telah disalurkan. Jika pembiayaan yang disalurkan meningkat maka berdampak pada peningkatan penghasilan. penghasilan yang meningkat akan mempengaruhi laba bersih.

\section{Pengembangan Hipotesis \\ Pengaruh Pendapatan Murabahah Terhadap Laba Bersih}

Pembiayaan murabahah merupakan salah satu bentuk untuk menyalurkan dana. Murabahah merupakan kesepakatan transaksi diantara pihak penjual dan pembeli dengan ditambah keuntungan yang telah disepakati. Dengan adanya transaksi jual beli tersebut pihak bank akan mendapatkan margin atau keuntungan yang telah ditentukan, keuntungan tersebut dapat meningkatkan pendapatan bank yang dapat mempengaruhi laba bersih perbankan syariah. Laba bersih secara positif dipengaruhi oleh murabahah didukung oleh penelitian Eva dan Herry (2019). 
$H a_{1}$ : Adanya pengaruh positif pendapatan murabahah terhadap laba bersih.

\section{Pengaruh Pendapatan Ijarah Terhadap Laba Bersih}

Dengan adanya pembiayaan ijarah dapat meperoleh keuntungan pada pihak bank. Ijarah merupakan perjanjain sewamenyewa antara bank dan nasabah, dimana bank merupakan pihak pemberi sewa yang menyediakan barang ataupun jasa yang dapat digunakan dan menerima upah sewa yang dibayarkan oleh nasabah. Upah sewa tersebut dapat meningkatkan pendapatan bank yang mempengaruhi laba bersih. Laba bersih secara positif dipengaruhi oleh ijarah yang didukung oleh penelitian Vena Melinda (2018).

$\mathrm{Ha}_{2}$ : Adanya pengaruh positif pendapatan ijarah terhadap laba bersih.

\section{Pengaruh Pendapatan Murbahah Dan Pendapatan Ijarah Terhadap Laba Bersih}

Penyaluran pembiayaan yang dilakukan pihak bank dapat mempengaruhi tingkat pendapatan bank. Jika pembiayaan yang disalurkan meningkat maka pendapatan mengalami peningkatan. Pendapatan yang meningkat akan mempengaruhi laba bersih. Pendapatan murabahah dan pendapatan ijarah secara bersama-sama dapat mempengaruhi laba bersih, hal tersebut didukung oleh penelitian Siti Nuraeni (2019).

$\mathrm{Ha}_{3}$ : Adanya pengaruh positif pendapatan murabahah dan pendapatan ijarah secara simultan terhadap laba bersih

\section{METODE PENELITIAN}

Metode deskriptive dan verifikatif dengan pendekatan kuantitatif diguanakan oleh penulis sebagai metode riset dan bank umum syariah digunakan penulis sebagai object riset. Data sekunder berupa laporan keuangan tahunan. Jumlah populasi pada riset ini sebanyak 11 bank umum syariah periode 2013-2019. Purposive sampling digunakan sebagai pemilihan sempel. Berdasarkan kriteria tersebut Ada 3 sampel yang digunakan oleh peneliti yaitu Bank BNI Syariah, Bank Syariah Mandiri, dan Bank Mega Syariah. Analisis data dilakukan dengan menggunakan regresi berganda dengan alat bantu SPSS versi 25

\section{HASIL DAN PEMBAHASAN}

Analisis Deskriptif

Analisis deskriptif menggambarkan setiap variabel tanpa membandingkan dengan variabel lain. Berikut hasil statistic deskriptive:

Tabel 1 Descriptive Statistics

\begin{tabular}{cccccc}
\hline & N & Minimum & Maximum & Mean & $\begin{array}{c}\text { Std. } \\
\text { Deviation }\end{array}$ \\
\hline MURABAHAH & 20 & 426293 & 4565808 & 2100126,30 & 1448215,291 \\
IJARAH & 20 & 100 & 145568 & 39176,10 & 42674,579 \\
$\begin{array}{c}\text { LABA } \\
\text { BERSIH }\end{array}$ & 20 & -44810 & 651240 & 238124,90 & 208621,263 \\
\hline
\end{tabular}

Sumber : Output SPSS 25.0 
Berdasarkan tabel 1 diketahui bahwa nilai $\mathrm{N}$ atau jumlah sampel pada masingmasing variabel berjumlah 20 data. Pada tabel 1 diketahui pendapatan murabahah dengan nilai min sebesar 426.293 sampai dengan nilai max sebesar 4.565.808. mean sebesar 2.100.126,30 dan standar deviation sebesar 1.448.215,291 memperlihatkan penyebaran data normal. Ijarah menunjukkan nilai min 100 sedangkan nilai max 145.568 dan mean sebesar 39.176,10 sedangkan standar deviation sebesar 42.674,579 standar deviasi lebih tinggi dari mean menunjukkan tingkat penyimpangan yang tinggi. Dan laba bersih memiliki nilai min sebesar -44.810 sampai dengan nilai max sebesar 651.240 dengan nilai mean sebesar 238.124,90 dan standar deviation sebesar 208.621,263 memperlihatkan penyebaran data normal.

\section{Uji Asumsi Klasik}

Tabel 2 Uji Normalitas

One-Sample Kolmogorov-Smirnov Test

\begin{tabular}{c|c|c}
\hline \multicolumn{2}{|c|}{} & Unstandardized Residual \\
\hline \multicolumn{2}{c}{$\mathbf{N}$} & 20 \\
\hline \multirow{2}{*}{$\begin{array}{c}\text { Normal } \\
\text { Parameters }\end{array}$} & Mean & 0,0000000 \\
\cline { 2 - 3 } & Std. Deviation & 161203,24315727 \\
\hline $\begin{array}{c}\text { Most } \\
\text { Extreme } \\
\text { Differences }\end{array}$ & Absolute & 0,153 \\
\cline { 2 - 3 } & Positive & 0,125 \\
\cline { 2 - 3 } Test Statistic & $-0,153$ \\
\hline \multicolumn{2}{c}{ Negative } & 0,153 \\
\hline \multicolumn{2}{c}{ Asymp. Sig. (2-tailed) } &, $200^{\mathrm{c}, \mathrm{d}}$ \\
\hline
\end{tabular}

Sumber : Output SPSS 25.0

Berdasarkan tabel 2 memperlihatkan nilai Asymp. Sig 0,200 dimana menunjukkan data tersebut normal karena $>0,05$

Tabel 3 Uji Multikolinearitas

Coefficients $^{\mathrm{a}}$

\begin{tabular}{c|c|c|c}
\hline Model & & \multicolumn{2}{|c}{$\begin{array}{c}\text { Collinearity } \\
\text { Statistics }\end{array}$} \\
\hline & & Tolerance & VIF \\
\hline $\mathbf{1}$ & (Constant) & & \\
\hline & MURABAHAH & 0,734 & 1,363 \\
\hline & IJARAH & 0,734 & 1,363 \\
\hline
\end{tabular}

Sumber : Output SPSS 25.0 
Tabel 3 menunjukkan nilai VIF pendapatan murabahah $1,363<10$ dan nilai toleransi $0,734>0,10$. Sedangkan nilai VIF pendapatan ijarah $1,363<10$ dan nilai tolerancenya $0,734>0,10$. Dengan demikian, dapat disimpulkan tidak terjadi multikolinearitas.

Tabel 4 Uji Heteroskedastisitas

\section{Coefficients $^{\text {a }}$}

\begin{tabular}{|c|c|c|c|}
\hline \multicolumn{2}{|c|}{ Model } & $\mathbf{T}$ & Sig. \\
\hline \multirow[t]{3}{*}{1} & (Constant) & 2,826 & 0,012 \\
\hline & MURABAHAH & 0,949 & 0,357 \\
\hline & IJARAH & $-0,756$ & 0,460 \\
\hline
\end{tabular}

Sumber : Output SPSS 25.0

Pada tabel 4 menunjukkan nilai signifikan pendapatan murabahah 0,357 dan pendapatan ijarah 0,460 . Telihat nilai sign setiap variabel $>0,05$, hingga tidak terjadi heteroskedastisitas

Tabel 5 Uji Autokorelasi Model Summary ${ }^{\mathrm{b}}$

\begin{tabular}{c|c}
\hline Model & Durbin-Watson \\
\hline $\mathbf{1}$ & 1,556 \\
\hline
\end{tabular}

Sumber : Output SPSS 25.0

Tabel 5 menunjukkan nilai $D W 1,556$ ada diantara -2 hingga 2. Sehingga tidak ada autokorelasi dalam model regresi

\section{Analisis Regresi Berganda}

Tabel 6 Uji Hipotesis (Uji F)

ANOVA ${ }^{a}$

\begin{tabular}{|l|l|l}
\hline Model & F & Sig. \\
\hline
\end{tabular}




\begin{tabular}{|l|l|l|l}
\hline $\mathbf{1}$ & Regression & 5,736 &, $012^{\mathrm{b}}$ \\
\hline & Residual & & \\
\hline & Total & & \\
\hline
\end{tabular}

Sumber : Output SPSS 25.0

Pada tabel 6 menunjukkan nilai $F_{\text {hitung }}$ $5,736>3,55 F_{\text {tabel }}$ dan signiifikan $0,012<$
0,05, Sehingga dinyatakan bahwa $\mathrm{Ha}_{3}$ diterima.

\section{Koefisien Determinasi $\left(R^{2}\right)$}

Tabel 7 Uji Determinasi

Model Summaryb

\begin{tabular}{c|c}
\hline Model & R Square \\
\hline $\mathbf{1}$ & 0,403 \\
\hline
\end{tabular}

Sumber : Output SPSS 25.0

Nilai R Square pada tabel 7 adalah

faktor lainnya seperti mudharabah, 0,403 atau 40,3\%, sisanya 59,7\% dipengaruhi musyarakah, dan lainnya.

Tabel 8 Analisis Regresi Berganda

Coefficients $^{\mathrm{a}}$

\begin{tabular}{c|c|c|c}
\hline Model & & \multicolumn{2}{|c}{$\begin{array}{c}\text { Unstandardized } \\
\text { Coefficients }\end{array}$} \\
\hline & & B & Std. Error \\
\hline \multirow{2}{*}{1} & (Constant) & 48749,106 & 68752,423 \\
\cline { 2 - 4 } & MURABAHAH & 0,095 & 0,032 \\
\cline { 2 - 4 } & IJARAH & $-0,285$ & 1,069 \\
\hline
\end{tabular}

Sumber : Output SPSS 25.0

Berikut model regresi yang diperoleh, yaitu :

$$
\mathrm{Y}: 48749,106+0,095 \mathrm{X} 1-0,285 \mathrm{X} 2
$$

Persamaan regresi berganda tersebut menyatakan bahwa apabila pendapatan murabahah dan pendapatan ijarah bernilai 0 maka dapat mempengaruhi jumlah dari laba bersih sebesar 48749,106. Pada koefisien regresi $X_{1}$ menunjukkan apabila pendapatan murabahah mengalami peningkatan 1 rupiah maka laba bersih bernilai sebesar 0,095. Pada koefisien regresi $X_{2}$ menunjukkan jika pendapatan ijarah meningkat 1 rupiah maka diikuti dengan penurunan laba bersih sebesar $-0,285$. 
Tabel 9 Uji Hipotesis (Uji T)

Coefficients $^{\mathbf{a}}$

\begin{tabular}{|c|c|c|c|}
\hline Model & & $\mathbf{T}$ & Sig. \\
\hline & & & \\
\hline \multirow[t]{3}{*}{1} & (Constant) & 0,709 & 0,488 \\
\hline & MURABAHAH & 3,030 & 0,008 \\
\hline & IJARAH & $-0,266$ & 0,793 \\
\hline
\end{tabular}

Sumber : Output SPSS 25.0

Pengaruh pendapatan murabahah terhadap laba bersih

Adanya pengaruh positif pendapatan murabahah terhadap laba bersih Pada tabel 9 hasil yang diperoleh menunjukkan nilai signifikan pada pendapatan murabahah sebesar 0,008. Sedangkan pada nilai $t_{\text {hitung }}$ pendapatan murabahah sebesar 3,030 dan $t_{\text {tabel }}$ sebesar 2,110 yang didapat dari (df;nk-1). Dengan demikian, nilai sign $0,008<0,05$ dan nilai $t_{\text {hitung }} 3,030>2,110$ nilai $t_{\text {tabel }}$. Hal tersebut menunjukkan bahwa $\mathrm{Ha}_{1}$ diterima.

\section{Pengaruh pendapatan ijarah terhadap laba bersih}

Adanya pengaruh positif pendapatan ijarah terhadap laba bersih Pada tabel 9 memperoleh hasil dengan nilai sign $0,793>0,005$ dan nilai $t_{\text {hitung }}-0,285<2,110$ nilai $t_{\text {tabel }}$. Hal tersebut menunjukkan bahwa $\mathrm{Ha}_{2}$ ditolak.

\section{KESIMPULAN}

Dengan demikian dapat memperoleh kesimpulan, yaitu. Pertama, Hasil uji hipotesis atau uji-t pendapatan murabahah memperlihatkan adanya pengaruh positif signifikan terhadap laba bersih. Hal tersebut ditunjukkan karena nilai signifikansi $0,008<0,005$ dan nilai $t_{\text {hitung }} 3,030>2,110$ nilai $t_{\text {tabel }}$. Kedua, Hasil uji hipotesis uji-t pendapatan ijarah secara parsial tidak berpengaruh signifikan terhadap laba bersih. Hal tersebut tunjukkan karena nilai signifikansi sebesar 0,793 dan nilai $t_{\text {hitung }}{ }^{-}$ $0,285<2,110$ nilai $t_{\text {tabel }}$. Dan terakhir Hasil uji determinasi memperlihatkan nilai $\mathrm{R}$ Square 0,403 atau 40,3\%, artinya kemampuan model regresi dalam menjelaskan laba bersih sebesar 40,3\%.

\section{DAFTAR PUSTAKA}

Djamil Fathurrahman, M. (2013). Penerapan Hukum Perjanjian Dalam Transaksi Di Lembaga Keuangan Syariah. Jakarta: Sinar Grafika

Fatwa Dewan Syari'ah Nasional No: 09/DSN-MUI/IV/2000 tentang Ijarah.

Ferieka, Hendrieta. (2016). Pengantar Akuntansi. Depok: CV Media Damar Mandani.

Fitri, vena Melinda. (2018). Pengaruh Pendapatan Ijarah Terhadap Laba Pada Bank Umum Syariah (periode 20152017). Thesis, Universitas Islam Negeri Banten. 
Kasmir. (2011). Analisis Laporan Keuangan. Jakarta: Raja Grafindo Persada.

Muljono, Djoko. (2015). Perbankan dan Lembaga Keuangan Syari'ah. Yogyakarta: ANDI..

Nurhayati, Sri dan Wasilah. (2013). Akuntansi Syariah Di Indonesia Edisi 3. Jakarta: Salemba Empat.

Sudarsono, Heri.(2012). Bank Dan Lembaga Keuangan Syariah:Deskripsi Dan Ilustrasi. Yogyakarta: Ekosoria

Undang-Undang Republik Indonesia Nomor 10 Tahun 1998 Tentang Perubahan Atas Undang-Undang Nomor 7 Tahun 1992 Tentang Perbankan Pasal 1.

Winarto, H., dan Nuraisyah, E. (2019). Analisis Pengaruh Pendapatan Margin Murabahah Dan Pendapatan Bagi Hasil Musyarakah Terhadap Laba Bersih PT Bank Negara Indonesia Syariah (Periode Tahun 2012-2018). Jurnal Akuntansi dan Bisnis Krisnadwipayana, Vol. 6 No. 3 h. 68 . 